\title{
Introduksi Teknologi Budi Daya Hidroponik bagi Kelompok Calon Wirausaha di Masa Pandemi Covid-19
}

\section{(Introduction of Hydroponic Cultivation Technology for Entrepreneurial Candidates During the Covid-19 Pandemic)}

\author{
Azhar Bafadal ${ }^{*}$, Teguh Wijayanto ${ }^{2}$, Surni' ${ }^{1}$, Hadi Sudarmo ${ }^{1}$, Zohorman $^{3}$ \\ 1 Jurusan Agribisnis, Fakultas Pertanian, Universitas Halu Oleo, Kampus Bumi Tridharma Anduonohu, Kendari 93231. \\ 2 Jurusan Agroteknologi, Fakultas Pertanian, Universitas Halu Oleo, Kampus Bumi Tridharma Anduonohu, Kendari 93231. \\ ${ }^{3}$ Ketua Kelompok Usaha Hidroponik Tekbek, Jl. Ade Irma Nasution Lr. Hidroponik No. 1 Kelurahan Watubangga \\ Kecamatan Baruga, Kota Kendari 93116. \\ *Penulis korespondensi: azharbafadal@yahoo.com \\ Diterima November 2020/Disetujui Juli 2021
}

\begin{abstract}
ABSTRAK
Tujuan kegiatan ini adalah memberikan pengetahuan dan keterampilan bagi masyarakat calon wirausaha yang terdampak pandemi Covid-19 dalam teknik budi daya hidroponik secara mumpuni. Metode pelaksanaan kegiatan berupa pelatihan dalam ruangan mengenai konsep dan teknik budi daya hidroponik. Selain itu, juga dilakukan bimibingan teknis di luar ruangan mengenai pembuatan instalasi hidroponik dan praktik budi daya yang dimulai dari pembuatan nutrisi, penyemaian benih, penanaman, hingga panen. Metode kunjungan lapang ke wirausaha hidroponik yang sudah berhasil juga dilakukan. Peserta dapat mengikuti dengan baik materi pelatihan dan bimbingan teknis perakitan instalasi serta praktik budi daya hidroponik. Manfaat dan tingkat kepuasan peserta dalam mengikuti kegiatan ini mencapai skor 8,75. Kegiatan ini meningkatkan minat peserta pelatihan untuk berwirausaha hidroponik. Kondisi tanaman yang dipanen belum memberikan hasil sebagaimana yang diharapkan, dengan hasil panen masih sekitar $50 \%$ dari potensi yang dapat dicapai. Untuk memastikan keberlanjutan kegiatan dan memiliki dampak yang lebih meluas maka sebaiknya pihak Kelurahan Konda dapat memfasilitasi agar peserta kegiatan ini dapat menjadi tutor bagi masyarakat lainnya yang ingin berwirausaha hidroponik.
\end{abstract}

Kata kunci: hidroponik, pandemi, wirausaha

\begin{abstract}
The purpose of this activity is to provide knowledge and skills for prospective entrepreneurs affected by the Covid-19 Pandemic in qualified hydroponic cultivation techniques. The method of implementing the activity is in the form of indoor training on the concepts and techniques of hydroponic cultivation. In addition, outdoor technical guidance is also carried out regarding the construction of hydroponic installations and cultivation practices, starting from making nutrition, sowing seeds, planting to harvesting. The method of field visits to successful hydroponic entrepreneurs is also carried out. Participants can properly follow the training materials and technical guidance on assembling installations and practicing hydroponic cultivation. The benefits and level of satisfaction of participants in participating in this activity reached a score of 8.75. This activity increases the interest of the training participants for hydroponic entrepreneurship. The condition of the harvested plants has not yielded the expected results, with yields still around $50 \%$ of the achievable potential. To ensure the sustainability of the activity and have a wider impact, the Konda Village Party should facilitate so that the participants of this activity can become tutors for other people who want to do hydroponic entrepreneurship.
\end{abstract}

Keywords: entrepreneur, hydroponics, pandemic

\section{PENDAHULUAN}

Pandemi Covid-19 yang mulai melanda Indonesia termasuk di Provinsi Sulawesi Tenggara sejak bulan Maret 2020 memberikan dampak langsung kepada kehidupan dan perekonomian masyarakat. Pengurangan atau pembatasan aktifitas masyarakat di luar rumah membuat kehidupan tidak berjalan normal sebagaimana biasanya, sehingga membuat lemahnya sendi ekonomi keluarga akibat pengurangan pendapatan sementara kebutuhan tidak mengalami penurunan bahkan cenderung meningkat. Pandemi Covid-19 menimbulkan gangguan pada operasi rantai nilai dan 
mengancam keberlangsungan operasi dunia usaha di berbagai sektor (Budastra 2020). Pada Sektor perikanan yang dilakukan oleh nelayan, diprediksi akan terjadi trend pendapatan menurun tajam hingga bulan Desember, dan akan berhutang mulai bulan Juli-Desember 2020 (Kholis et al. 2020).

Sejak pembatasan aktifitas di luar rumah diberlakukan membuat beberapa pihak mengalami penurunan pendapatan, seperti karyawan hotel dan toko yang dirumahkan, pekerja informal yang mengalami penurunan omzet penjualan secara drastis, dan pendapatan riil petani yang menurun akibat menurunnya permintaan pasar sementara pengeluaran rumah tangga meningkat akibat inflasi. Sektor rumah tangga pun mengalami stagnasi dan bahkan penurunan tajam dalam pendapatan rumah tangga karena banyak terjadinya pemutusan hubungan kerja (PHK). Pemutusan hubungan kerja (PHK) ini semakin memperburuk kondisi ekonomi pekerja yang di PHK sehingga berbagai kebutuhan pun tak dapat di penuhi (Sina 2020). Kondisi di atas dialami oleh semua rumah tangga, tidak terkecuali rumah tangga di daerah penyangga suatu perkotaan seperti di Kelurahan Konda, Kecamatan Konda, Kabupaten Konawe Selatan, Provinsi Sulawesi Tenggara. Di sisi lain, krisis pandemi dapat menjadi motor penggerak integrasi global terkait bioekonomi, terutama implementasi tujuan pembangunan berkelanjutan, pengembangan strategi bioekonomi nasional dan regional, peningkatan pentingnya ekonomi sirkular, jaminan ketahanan pangan serta keberlanjutan produksi pangan, dan perlindungan keanekaragaman hayati (Mahi et al. 2021).

Hasil survei di Kelurahan Konda, Kecamatan Konda, Kabupaten Konawe Selatan, Provinsi Sulawesi Tenggara menunjukkan bahwa masih terdapat banyak potensi lahan pekarangan masyarakat yang belum dimanfaatkan secara memadai untuk menopang perekonomian rumah tangga khususnya selama pandemi Covid-19. Dari sisi produksi, kondisi tersebut menjadi sumber peluang pendapatan dengan cara pemanfaatan pekarangan melalui konsep tanaman hidroponik yang dapat dilakukan walaupun tanpa pekarangan yang luas. Pada sisi manajemen, pengusahaan tanaman hidroponik dapat dilakukan secara individu maupun secara berkelompok. Potensi ini dimiliki oleh masyarakat Kelurahan Konda dimana mereka telah memiliki kelompok usaha sehingga peluang baik untuk dikembangkan melaui introduksi tanaman hidroponik.
Konsep bertanam hidroponik memberikan beberapa keunggulan atau kelebihan disbandingkan dengan cara tanam secara konvensional. Keunggulan tanaman hidroponik di antaranya tanaman berproduksi tanpa menggunakan tanah dan penggunaan lahan efisien, kuantitas dan kualitas produksi lebih tinggi dan lebih bersih, penggunaan pupuk dan air lebih efisien, pengendalian hama dan penyakit lebih mudah (Distan Sukabumi 2020). Kelebihan lain tanaman hidroponik adalah 30-50\% tingkat pertumbuhan lebih cepat, tak ada nutrisi terbuang, pemakaian pestisida bisa ditekan, pekerjaan mudah dan effisien, serta serangan hama dan penyakit yang sedikit (Bibitonline 2020).

Sasaran introduksi teknologi tanaman hidroponik di Kelurahan Konda adalah kelompok masyarakat yang terdampak Covid-19 dan mempunyai keinginan kuat menjadi wirausaha dan berhasrat kuat mengembangkannya di masa mendatang. Pemilihan kelompok tersebut berdasarkan pertimbangan bahwa teknik budi daya hidroponik akan dapat dilakukan oleh kelompok tersebut mengingat teknik hidroponik ini tidak sulit dilakukan dan dapat dilakukan di halaman atau pekarangan rumah sehingga memudahkan para calon kelompok wirausaha ini seperti ibu rumah tangga yang lebih sering berada di rumah untuk menanganinya. Bahkan, kelompok dasa wisma Pasarbaru Jakarta telah mempraktikkan hal ini di mana berhasil memanen sawi dan pakchoy dan menjualnya dengan harga Rp10.000 per ikat (Berita Jakarta, 2020). Sebagian besar sayuran hidroponik yang diusahakan adalah dalam skala rumah tangga. Pada umumnya sayuran yang diusahakan adalah selada hijau, pakcoy, sawi, bayam, dan kangkung. Pendapatan kelima jenis sayuran sebesar Rp1.875.550 dengan keuntungan Rp1.251.260, R/C ratio sebesar 1,47 yang artinya bahwa usaha tani sayuran hidroponik layak untuk diusahakan sebagai sumber pendapatan (Kilmanun \& Ndaru 2020).

Penurunan pendapatan rumah tangga semestinya perlu disubstitusi atau paling tidak disangga melalui upaya penciptaan sumber pendapatan lainnya yang dapat diciptakan melalui peningkatan pengetahuan dan keterampilan serta perluasan pasar produk hidroponik. Upaya tersebut penting dilakukan sehingga masyarakat yang terkena dampak Covid-19 dapat menemukan sumber penghasilan baru yang dapat menyangga perekonomian keluarganya. Salah satu cara yang dapat dilakukan adalah dengan melakukan kegiatan optimalisasi pekarangan bagi calon wirausaha. 
Kegiatan optimalisasi pekarangan merupakan salah satu kegiatan yang dapat dilakukan di masa pandemi Covid-19 untuk mencegah terjadinya krisis pangan (Swardana 2020). Teknologi budi daya pertanian dengan sistem hidroponik diharapkan menjadi salah satu alternatif bagi masyarakat yang mempunyai lahan terbatas atau pekarangan, sehingga dapat dijadikan sebagai sumber penghasilan yang memadai (Roidah 2014).

Hasil yang diharapkan dari kegiatan ini adalah terciptanya wirausaha baru hidroponik melalui pemanfaatan pekarangan secara produktif. Tujuan kegiatan ini adalah memberikan pengetahuan dan keterampilan bagi masyarakat calon wirausaha yang terdampak Pandemi Covid-19 dalam teknik budi daya hidroponik secara mumpuni. Dalam jangka panjang diharapkan dari hasil kegiatan ini dapat dikembangkan lebih lanjut sehingga peserta kegiatan dapat menjadi seorang wirausaha hidroponik yang kreatif agar dapat memberikan kontribusi pada pendapatan keluarga.

\section{METODE PELAKSANAAN KEGIATAN}

\section{Lokasi, Partisipan, dan Waktu Kegiatan}

Kegiatan ini dilaksanakan di Kelurahan Konda, Kecamatan Konda, Kabupaten Konawe Selatan, Provinsi Sulawesi Tenggara. Peserta kegiatan adalah calon wirausaha Kelompok Mepokoaso yang berjumlah 15 orang. Pelaksanaan kegiatan pada bulan SeptemberDesember 2020.

\section{Bahan dan Alat}

Bahan dan alat yang digunakan untuk melaksanakan kegiatan ini terdiri atas bahan untuk transfer pengatahuan di dalam kelas seperti laptop, infokus, alat tulis untuk peserta. Selain itu, diperlukan bahan untuk kegiatan praktik taman hidroponik, baik untuk perakitan instalasi dan untuk keperluan budi daya tanamannya.

Bahan untuk perakitan instalasi hidroponik meliputi seperangkat pipa paralon, pompa celup kolam, ember penampungan nutrisi berkapasitas $40 \mathrm{~L}$. Alat yg digunakan, yaitu gergaji besi, mesin bor, mesin gurinda. Adapun bahan untuk keperluan budi daya tanaman hidroponik meliputi nampan penyemaian, rockwool, nutiris $\mathrm{AB}$ mix, benih selada, benih pakchoy, dan benih kangkung. Alat yang digunakan untuk keperluan budi daya tanaman yaitu TDS meter dan $\mathrm{pH}$ meter.

\section{Metode Pelaksanaan Kegiatan}

Metode pelaksanaan kegiatan, yaitu dengan menyeleggarakan pelatihan di dalam ruangan dan bimbingan teknis di luar ruangan. Pelatihan tersebut menyangkut berwirausaha dalam pandemi Covid-19, teknik budi daya hidroponik yang dimulai dari transfer pengetahuan di dalam kelas melalui ceramah dengan menggunakan bantuan laptop dan infocus dan alat peraga hidroponik. Selain itu, dilakukan juga bimbingan teknis perakitan perangkat atau instalasi hidroponik yang dilaksanakan di luar ruangan, sehingga lebih memudahkan peserta pelatihan dalam memahami materi yang diberikan dalam ruangan. Setelah perangkat selesai maka dilakukan uji coba penanaman dengan menggunakan perangkat yang sudah dirakit dalam bimbingan teknis tersebut, dan selanjutnya peserta memelihara tanaman tersebut. Selain itu, peserta kegiatan melakukan kunjungan pembelajaran ke wirausaha hidroponik Tekbek yang sudah berjalan dengan harapan akan timbul motivasi yang kuat untuk berwirausaha setelah melihat secara langsung pertanaman hidroponik.

\section{Metode Pengumpulan Data}

Data yang diperlukan untuk mengetahui pemahaman tentang tanaman hidroponik dilakukan melalui pre-test dan post-test. Sedangkan untuk mengetahui perkembangan tanaman maka dilakukan monitoring oleh tim dua kali dalam seminggu dan untuk hal ini dilakukan dengan dokumentasi foto.

\section{Metode Pengolahan dan Analisis Data}

Data hasil pre-test dan post test kemudian ditabulasi untuk melihat perbedaan jawaban dari peserta sebelum dan sesudah melaksanakan pelatihan. Monitoring terhadap tanaman yang dilakukan seminggu dua kali didokumentasikan melalui foto untuk melihat perubahan perkembangan tanaman secara visual.

Analisis data dilakukan secara tabulasi untuk data hasil pre-test dan post-test dan kemudian diilustarasikan secara deskriptif dengan mengkaitkan pada situasi lapangan. Analisis data mengenai perkembangan tanaman dilakukan secara deskriptif setelah melihat perkembangan dari waktu ke waktu. 


\section{HASIL DAN PEMBAHASAN}

\section{Pelaksanaan Kegiatan Pelatihan}

Program Kemitraan Masyarakat Internal (PKMI) Universitas Halu Oleo ini menerapkan protokol kesehatan Covid-19 di mana dalam pelatihan dan bimbingan teknis semua pihak yang terlibat menggunakan masker. Peserta pelatihan dibagi atas dua sub kelompok dengan maksud agar proses transfer ilmu dan pengetahun dapat lebih efektif dan nantinya kedua sub kelompok ini akan bertanggug jawab terhadap instalasi dan tanaman hidroponiknya masing-masing. Secara ringkas partisipasi peserta dalam kegiatan ini adalah mengikuti pelatihan secara penuh sesuai dengan jadwal yang ditentukan, mengikuti bimbingan teknis dan praktik pembuatan perangkat hidroponik, mengikuti praktik penanaman dan bertanggung jawab dalam masa pemeliharaan tanaman sampai dengan panen.

Pelatihan teknik budi daya dilaksanakan di Balai Kelurahan Konda (Gambar 1). Pemateri pelatihan berasal dari tim PKMI dan pelaku wirausaha budi daya hidroponik yang tergabung dalam Kelompok Usaha Tekbek. Materi pelatihan yaitu program kemitraan masyarakat internal (PKMI) Unversitas Halu Oleo, menumbuhkan jiwa wirausaha hidroponik, budi daya tanaman secara hidroponik, ayo berhidroponik, teknik dan usaha hidroponik yang menjanjikan, dan teknik pemanfaatan teknologi informasi untuk pemasaran hidroponik. Berdasarkan materi yang diberikan tersebut diharapkan dapat dikembangkan lebih lanjut oleh peserta mengingat hal tersebut dapat memberikan manfaat yang besar secara sosial dan ekonomi. Menurut Tallei et al. (2017) bahwa hidroponik juga memiliki keuntungan bagi lingkungan sosial karena dapat dijadikan sarana pendidikan dan pelatihan

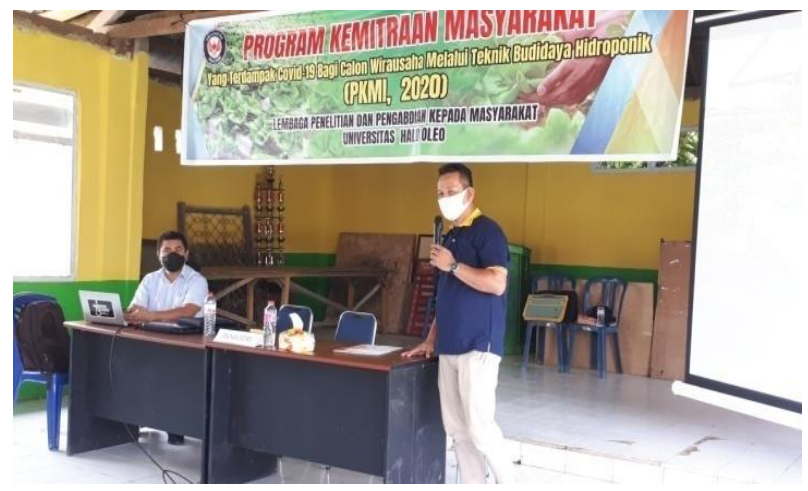

a dibidang pertanian modern mulai dari kanakkanak sampai dengan orang tua, memperindah lingkungan dengan kesan pertanian yang bersih dan sehat serta usaha agribisnis di pedesaan tanpa mencemari lingkungan.

\section{Bimbingan Teknis Perakitan Instalasi dan Persemaian Hidroponik}

Materi bimbingan teknis yang diberikan meliputi perakitan instalasi hidroponik, teknik persemaian benih, teknik pelarutan nutrisi, dan teknik budi daya hidroponik. Peserta kegiatan membuat dan merakit sendiri instalasi hidroponik yang berjumlah dua unit dengan bimbingan dari Tim PKMI dan Kelompok Tekbek. Bahan pembuatan hidroponik berasal dari pipa paralon, termasuk dudukan penyangganya. Waktu yang dihabiskan dalam perakitan ini selama setengah hari. Kegiatan perakitan instalasi hidroponik ini disajikan pada Gambar 2.

Kegiatan persemaian hidroponik dilakukan pada hari pertama pelatihan setelah pelatihan di kelas, yakni pada sore hari. Benih yang disemai adalah untuk tanaman pakchoy dan selada. Selain benih tanaman, bahan utama yang dipergunakan adalah rockwool sebagai media semai. Setiap benih disemai pada masing-masing lubang rockwood yang berukuran sekitar $2 \times 2 \mathrm{~cm}$. Setelah disemai dalam media rockwool maka benih tersebut disimpan pada nampan dengan perlakuan setiap pagi dan sore dipercikkan air dan pada waktu siang hari mendapat sinar matahari yang memadai. Dalam 2-3 hari setelah penyemaian maka benih yang disemai sudah muncul kecambah dan pelan-pelan akan muncul lembaran 2-3 daun. Proses persemaian ini memakan waktu selama empat belas hari untuk kemudian dipindahkan ke instalasi hidroponik. Gambar 3 memperlihatkan hasil persemaian benih.

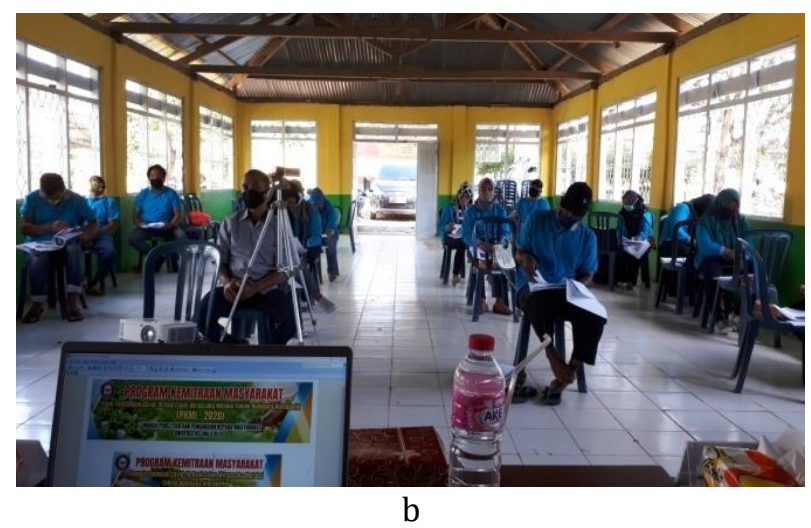

Gambar 1 a dan b Susana pelatihan hidroponik di Kelurahan Konda . 


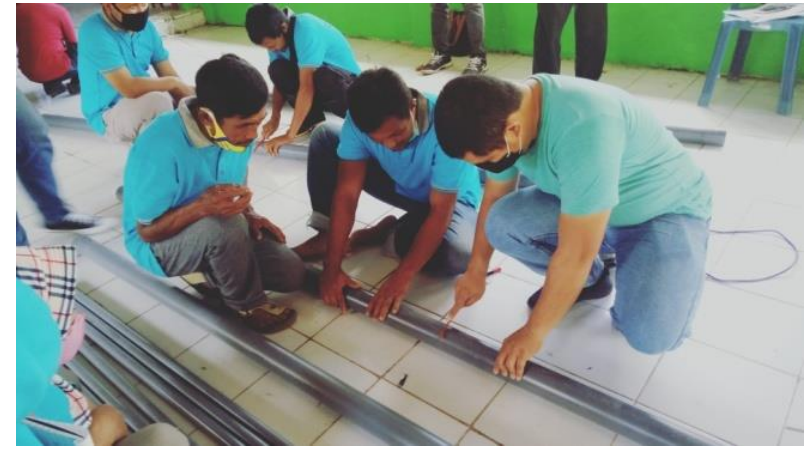

a

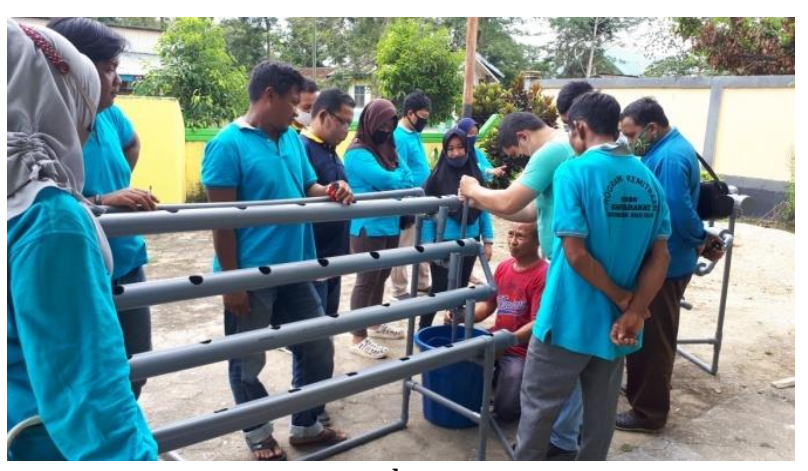

b

Gambar 2 a dan b Suasana perakitan instalasi hidroponik, Kelurahan Konda.

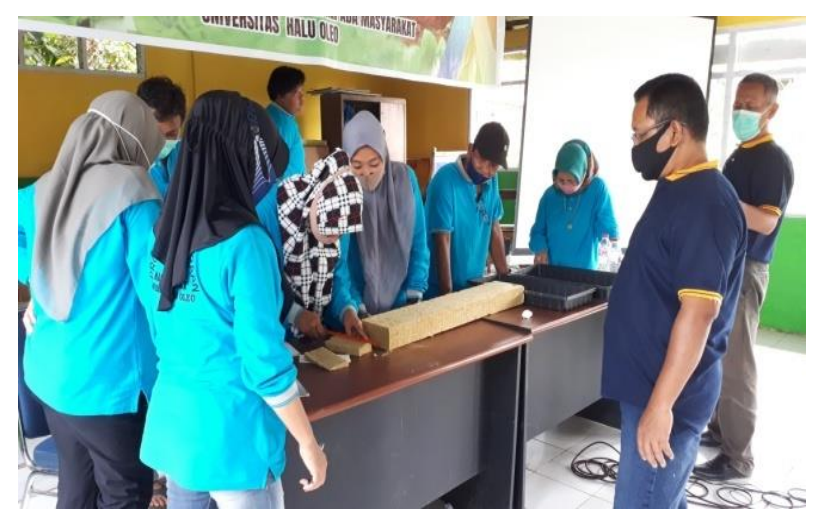

a

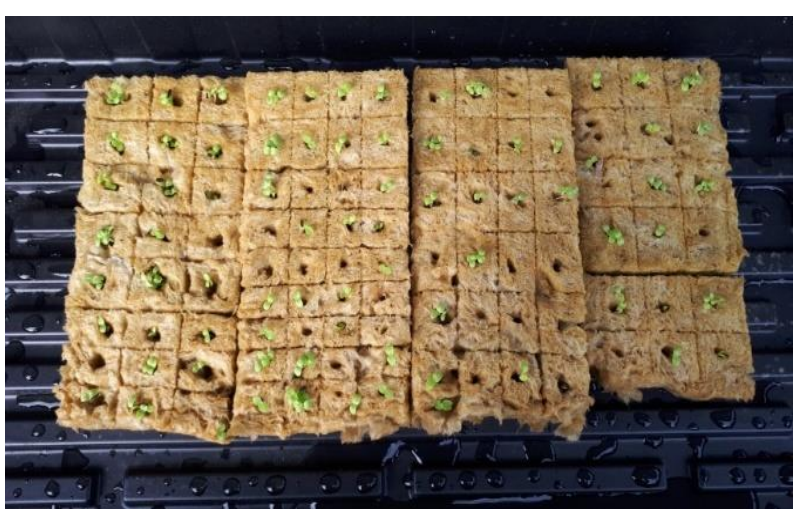

b

Gambar 3 a) Praktik pembuatan media persemaian dan b) Benih hidroponik yang telah disemai.

\section{Pembuatan Nutrisi}

Peserta diberikan pula bimbingan teknis cara pembuatan nutrisi dari bahan serbuk menjadi suatu larutan. Nutrisi adalah sumber makanan untuk tanaman hidroponik sehingga perlakuan nutrisi terhadap tanaman menjadi hal penting agar kelak tanaman dapat tumbuh subur sesuai harapan. Kualitas air menentukan dalam pembuatan nutrisi. Menurut Eikbuikwem et al. (2020) bahwa kekurangan nutrisi dan ketidakseimbangan dalam perlakuan sirkulasi air berkontribusi pada perkembangan yang buruk untuk aliran air tanaman. Nilai ppm air yang baik untuk larutan nutrisi yang terbentuk berada di atas 800 ppm. Nilai ppm ini harus dipertahankan sepanjang penanaman. Selain itu pula, ph larutan nutrisi yang baik berada pada kisaran 5,5-6,5. Suasana bimbingan pembuatan nutrisi diperlihatkan pada Gambar 4.

\section{Penanaman Hidroponik}

Ketika umur persemaian telah mencapai empat belas hari maka dilakukan pemindahan tanaman ke instalasi hidroponik yang telah dibuat sebelumnya. Setiap bibit tanaman yang berada di rockwool dipindahkan secara langsung ke net pot yang telah disiapkan dan kemudian
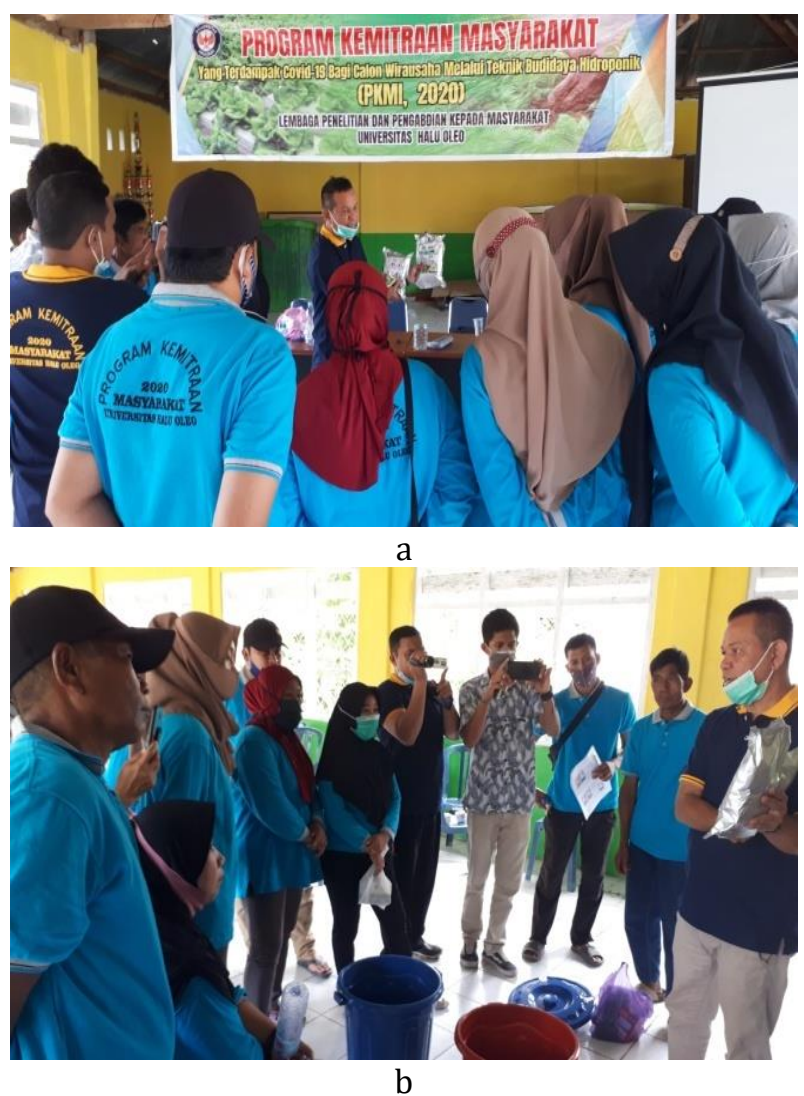

Gambar 4 a dan b Suasana bimbingan teknis pembuatan nutrisi. 
ditempatkan pada lubang pipa paralon yang didalamnya mengalir larutan nutrisi. Larutan nutrisi ini diangkat mengalir ke pipa paralon dengan menggunakan pompa air sebagaimana pompa air yang digunakan pada akuarium. Instalasi hidroponik tersebut harus berada pada tempat yang mendapat penyinaran matahari yang memadai agar pertumbuhan tanaman dapat maksimal. Selain itu, ketika usia tanaman masih muda agar mendapat perlindungan dari hujan deras yang dapat merusak tanaman. Kegiatan penanaman hidroponik ditunjukkan pada Gambar 5.

\section{Analisis Hasil Kegiatan}

Sebelum pelatihan dimulai diadakan pre-test untuk mengetahui sejauh mana pengetahuan peserta pelatihan terhadap budi daya hidroponik. Dari 12 peserta pelatihan yang mengisi pre-test terdapat 8 orang atau sebanyak $67 \%$ yang sudah mengetahui tentang tanaman hidroponik dan sisanya 4 orang (33\%) belum pernah mengetahui sebelumnya (Tabel 1). Kebanyakan peserta yang sudah mengetahui tanaman hidroponik tersebut mendapat informasi dari media sosial yakni sebanyak $62 \%$. Semua peserta pelatihan me-

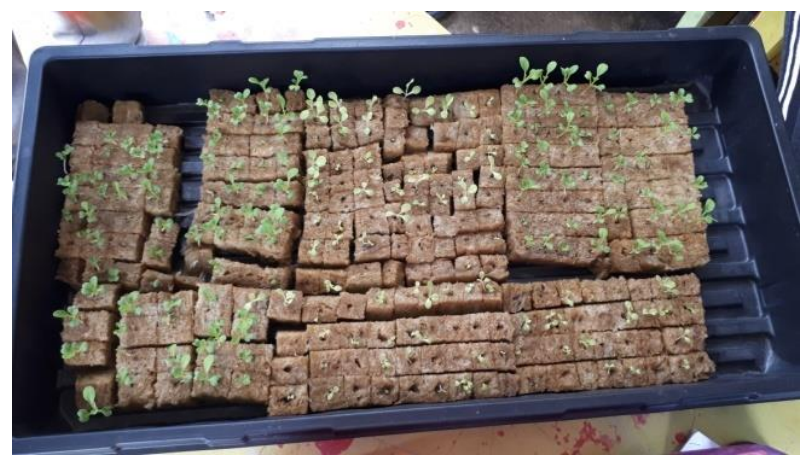

a nyatakan belum pernah mengikuti pelatihan tentang hidroponik sebelumnya. Sebanyak 83\% peserta memberikan alasan mengikuti pelatihan ini disebabkan keinginan untuk menambah pengetahuan dan keterampilan, dan $17 \%$ peserta menyatakan ingin berwirausaha hidroponik.

Berdasarkan hasil post-test sebagaimana yang ditunjukkan pada Tabel 2 tampak bahwa semua peserta kegiatan menyatakan bahwa mereka mengalami peningkatan pengetahuan dan keterampilan setelah mengikuti kegiatan ini. Kegiatan ini bermanfaat buat peserta dimana tingkat kepuasan mereka mencapai skor yang cukup tinggi yakni 8,75 . Sebanyak $75 \%$ peserta menyatakan keinginan mengusahakan tanaman hidroponik untuk kebutuhan sendiri (subsisten), dan yang tidak ingin menanam sebanyak $8 \%$, dan sisanya $17 \%$ menyatakan belum tahu.

Hal yang menggembirakan adalah peserta kegiatan yang ingin berwirausaha hidroponik setelah mengikuti kegiatan mencapai 67\%, dimana sebelum pelatihan dimulai hanya terdapat $17 \%$ peserta yang ingin berwirausaha hidroponik. Indikator tersebut menjadi pertanda bahwa harapan menjadikan peserta untuk berwirausaha setelah mengikuti kegiatan ini

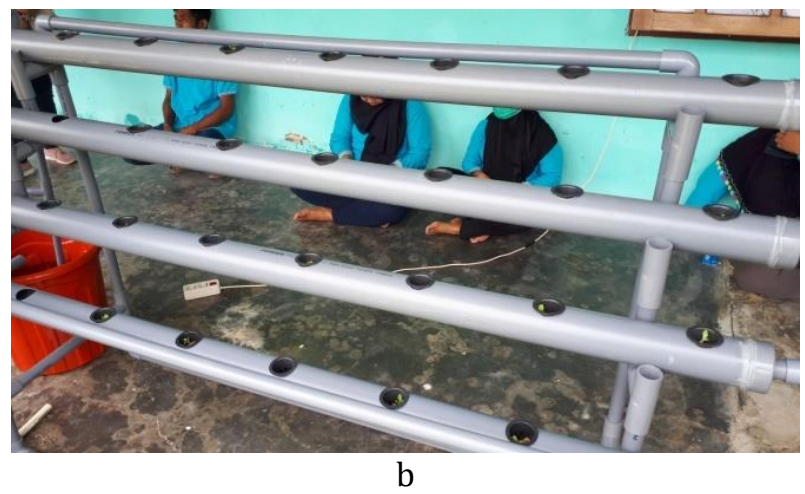

Gambar 5 a dan b Pemindahan tanaman dari persemaian ke instalasi hidroponik.

Tabel 1 Hasil pre-test peserta kegiatan

\begin{tabular}{|c|c|c|}
\hline Uraian & Jawaban & Keterangan \\
\hline $\begin{array}{l}\text { Apakah Saudara sudah pernah tahu } \\
\text { sebelumnya tentang tanaman } \\
\text { hidroponik? }\end{array}$ & $\begin{array}{l}\text { Sudah: } 67 \% \\
\text { Belum: } 33 \%\end{array}$ & $\begin{array}{l}\text { Kebanyakan peserta sudah mengetahui } \\
\text { tentang tanaman hidroponik }\end{array}$ \\
\hline $\begin{array}{l}\text { Dari mana Saudara tahu tentang } \\
\text { tanaman hidroponik tersebut? }\end{array}$ & $\begin{array}{l}\text { Televisi/radio: } 13 \% \\
\text { Media sosial/HP: } 62 \% \\
\text { Teman: } 25 \%\end{array}$ & $\begin{array}{l}\text { Pada umumnya peserta yang sudah } \\
\text { mengetahui tentang tanaman hidropnil } \\
\text { bersumber dari media sosial/HP }\end{array}$ \\
\hline $\begin{array}{l}\text { Apakah Saudara sudah pernah } \\
\text { mengikuti pelatihan hidroponik } \\
\text { sebelumnya? }\end{array}$ & Belum: 100\% & $\begin{array}{l}\text { Semua peserta belum pernah mengikuti } \\
\text { pelatihan hidroponik sebelumnya }\end{array}$ \\
\hline $\begin{array}{l}\text { Apa alasan Saudara ingin mengikuti } \\
\text { pelatihan hidroponik PKMI yang } \\
\text { dilaksanakan oleh UHO ini? }\end{array}$ & $\begin{array}{l}\text { Menambah pengetahuan } \\
\text { dan keterampilan: } 83 \% \\
\text { Ingin berwirausaha } \\
\text { hidroponik: } 17 \%\end{array}$ & $\begin{array}{l}\text { Umumnya peserta mengikuti dengan } \\
\text { alasan untuk menambah pengetahuan dan } \\
\text { keterampilan }\end{array}$ \\
\hline
\end{tabular}


Tabel 2 Hasil post-test peserta kegiatan

\begin{tabular}{|c|c|c|}
\hline Uraian & Jawaban & Keterangan \\
\hline $\begin{array}{l}\text { Apakah ada peningkatan pengetahuan } \\
\text { dan keterampilan dalam budi daya } \\
\text { hidroponik setelah mengikuti pelatihan } \\
\text { ini? }\end{array}$ & $100 \%$ & Semua peserta menyatakan ada \\
\hline $\begin{array}{l}\text { Berikanlah skor terhadap manfaat/ } \\
\text { kepuasan yang saudara rasakan dari } \\
\text { mengikuti pelatihan ini (skor } 1-10 \text {, skor } \\
1 \text { terendah, skor } 10 \text { tertinggi) }\end{array}$ & 8,75 & $\begin{array}{l}\text { Rata-rata skor yang diberikan oleh peserta } \\
\text { menunjukkan tingkat kepuasan yang tinggi }\end{array}$ \\
\hline Setelah mengikuti pelatihan ini apakah & Ya: $75 \%$ & Kebanyakan peserta ingin berhidroponik \\
\hline Saudara tertarik untuk mengusahakan & Tidak: $8 \%$ & untuk kebutuhan sendiri \\
\hline $\begin{array}{l}\text { tanaman hidroponik untuk kebutuhan } \\
\text { sendiri? }\end{array}$ & Belum tahu: $17 \%$ & \\
\hline Setelah mengikuti pelatihan ini apakah & Ya: $67 \%$ & Terdapat peningkatan keinginan \\
\hline $\begin{array}{l}\text { Saudara tertarik untuk berwirausaha } \\
\text { hidroponik? }\end{array}$ & Belum tahu: $33 \%$ & $\begin{array}{l}\text { berwirausaha hidroponik setelah mengikuti } \\
\text { pelatihan dari } 17 \text { menjadi } 67 \%\end{array}$ \\
\hline
\end{tabular}

cukup besar. Wirausaha hidroponik diharapkan dapat menjadi salah satu alternatif peningkatan pendapatan peserta pelatihan sehingga dapat membantu ekonomi rumah tangga. Peserta yang menyatakan belum tahu untuk menjadi wirausaha hidroponik dengan pertimbangan perlunya modal untuk memulai usaha tersebut, masih memikirkan untung ruginya usaha hidroponik, dan belum siap berwirausaha.

Pada budi daya tanaman, setelah bibit berada pada instalasi hidroponik maka setiap sub kelompok akan melakukan pemeliharaan dan bertanggung jawab atas tanaman mereka masing-masing. Instalasi hidoponik ini berada di rumah salah satu peserta pelatihan dengan pertimbangan keamanan dan pemeliharaan yang dapat lebih memadai dibandingkan jika instalasi tersebut berada di tempat umum seperti balai kelurahan.

Pemeliharaan tanaman merupakan tanggung jawab bersama anggota kelompok. Dalam jangka waktu seminggu dua kali atau sedikitnya sekali dalam seminggu Tim PKMI mengadakan monitoring perkembangan tanaman hidroponik. Pada permulaan tanan menunjukkan perkembangan tanaman yang cukup baik yang ditunjukkan mulai munculnya helai batang sayur dan terus menunjukkan pertumbuhan yang sesuai harapan. Namun, memasuki minggu kedua kondisi tanaman mengalami perlambatan dalam pertumbuhannya. Hasil monitoring menyatakan bahwa posisi tanaman kurang mendapat pencahayaan yang cukup sehingga disarankan untuk memindahkan ke tempat yang lebih terbuka.

Secara keseluruhan dapat dikatakan bahwa kondisi pertumbuhan tanaman belum mencapai hasil maksimal ditandai dengan kurang mekarnya daun tanaman dan pertumbuhan batang yang tidak maksimal. Kondisi tersebut dapat terjadi karena nilai ppm nutrisi yang kemungkinan tidak terjaga dengan baik. Menurut Wahyuningsih et al. (2016) bahwa perlakuan komposisi media dan nutrisi memberikan hasil berbeda nyata pada tanaman pakcoy terhadap semua parameter pertumbuhan, yaitu parameter jumlah daun pada umur pengamatan 18 dan 35 hari setelah tanam (hst), luas daun pada umur pengamatan 9 dan 35 hst, bobot segar total tanaman dan bobot segar konsumsi pada umur pengamatan 9, 18, dan 27 hst, dan bobot kering pada semua umur pengamatan. Berdasarkan hal tersebut maka dapat dikatakan bahwa perlakuan komposisi media dan nutrisi yang berbeda pada tanaman hidroponik memberikan hasil yang berbeda pula. Namun demikian, menurut Pihak Tekbek yang mendampingi dalam monitoring tanaman bahwa hal itu tidak menjadi masalah dan lazim terjadi pada penanaman pertama dimana peserta pelatihan masih dalam proses belajar. Pengalaman pada penanaman pertama ini menjadi modal berarti untuk mencoba pada penanaman berikutnya yang diharapkan dapat memeroleh hasil yang lebih baik. Kondisi pertumbuhan tanaman ditampilkan pada Gambar 6 .

Pemanenan tanaman dilakukan pada usia tanaman 34 hari. Kondisi tanaman hasil panen baru mencapai 50\% dari potensi hasil yang dapat dicapai. Hal tersebut disebabkan karena peserta pelatihan sebagai pemula belum memiliki pengalaman dalam berhidroponik. Tim telah memberikan saran agar dilakukan penanaman kedua kalinya dengan merubah posisi atau lokasi instalasi untuk mendapat sinar matahari yang cukup. Selain itu, peserta pelatihan harus memperhatikan dengan baik nilai ppm nutrisi sehingga tanaman memeroleh suplai makanan 

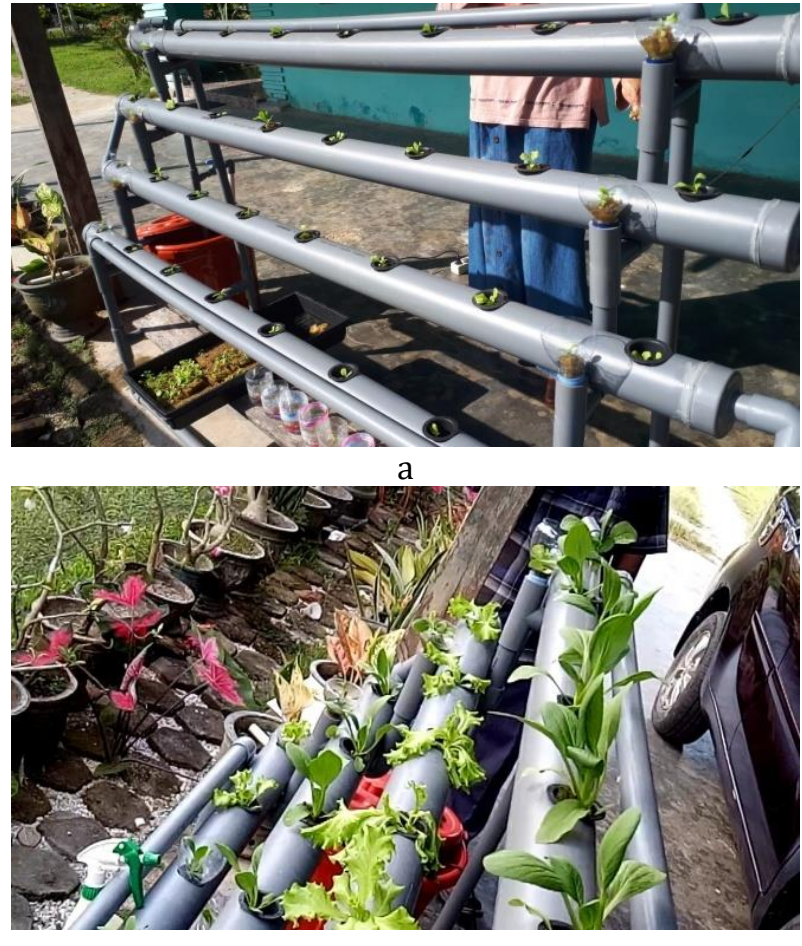

C

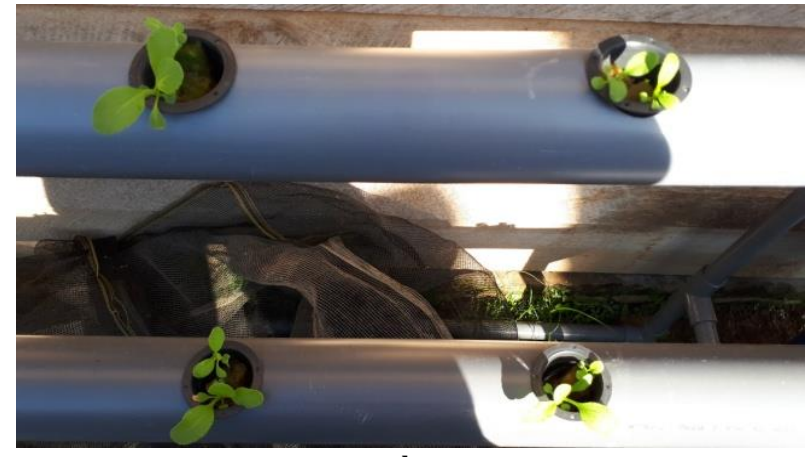

b

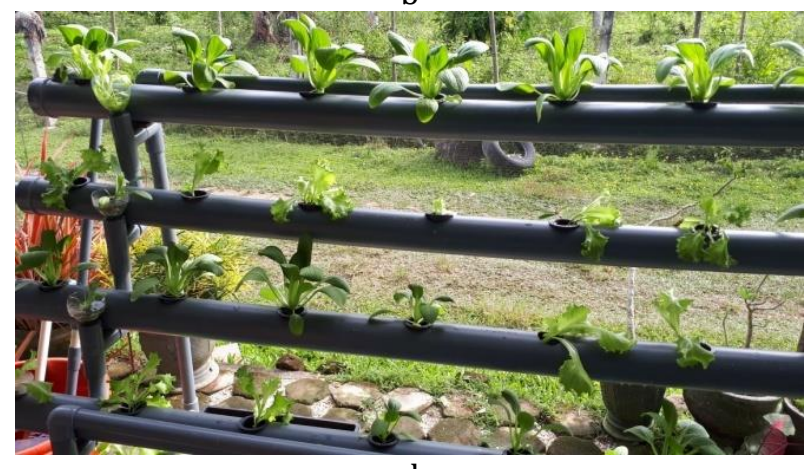

d

Gambar 6 Perkembangan tanaman hidroponik: a) 4 hari setelah tanam; b) 8 hari setelah tanam; c) 14 hari hari setelah tanam; dan d) 25 hari hari setelah tanam.

yang sesuai untuk merangsang pertumbuhannya. Kondisi tanaman sesaat sebelum panen ditunjukkan pada Gambar 7.

\section{Kendala Kegiatan}

Pada mulanya kegiatan ini dirancang untuk kelompok Dasawisma, namun mengingat keterbatasan dalam mengerjakan pembuatan instalasi hidrpoponik seperti dalam hal memotong paralon maka kegiatan ini mengikutsertakan juga laki-laki. Harpan pihak Pemerintah Kelurahan Konda agar masyarakat dapat lebih banyak yang ikut, namun harapan ini tidak sepenuhnya dapat dipenuhi mengingat anggaran yang terbatas dan juga situasi Pandemi Covid-19. Pada sisi lain, antusiasme peserta kegiatan tidak sepenuhnya seperti yang diharapkan, dimana peserta yang mengikuti seluruh rangkaian kegiatan sebanyak 12 orang. Penyerahan perangkat hidroponik sebanyak dua unit beserta bahan lainnya dapat menjadi kendala jika masing-masing peserta ingin menanam kembali sementara peralatan yang ada terbatas.

\section{Dampak dan Keberlanjutan Kegiatan}

Peserta pelatihan melakukan kunjungan pembelajaran ke usaha hidroponik Tekbek yang berada di Kecamatan Baruga, Kota Kendari. Kunjungan ini dimaksudkan agar peserta pelatihan dapat melihat langsung pertanaman hidroponik

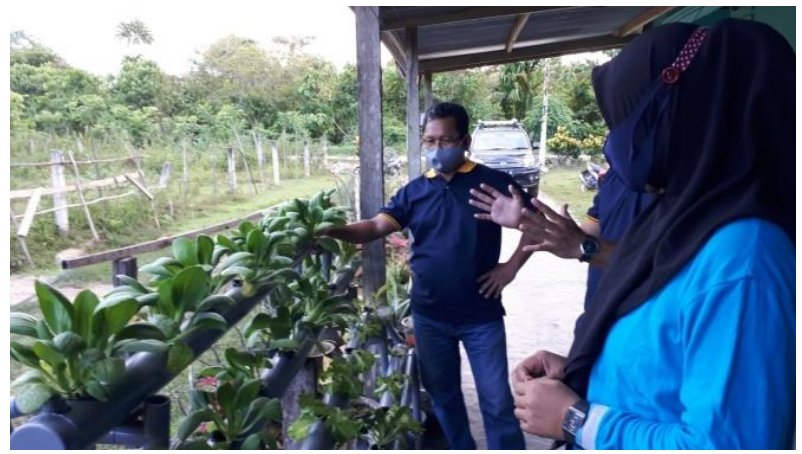

a

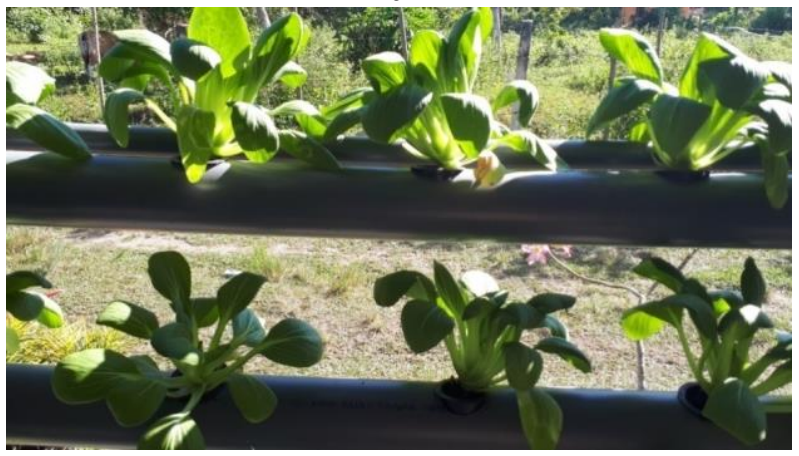

b

Gambar 7 a dan b Kondisi tanaman hidroponik sebelum panen.

sehingga dapat menimbulkan motivasi dan dampak untuk memulai menaman dan berwirausaha hidroponik. Dalam kegiatan ini ketua kelompok Tekbek memberikan penjelasan lapangan tentang tanaman hidroponik menyangkut konsruksi 
instalasi, teknik budi daya, penyemaian, pemeliharaan, dan nutrisi. Situasi pertanaman hidroponik kelompok Tekbek terlihat pada Gambar 8.

Pada kunjungan lapangan dijelaskan pula mengenai sejarah berdirinya usaha hidroponik Tekbek dan alasan memilih hidroponik sebagai usaha yang menjanjikan. Pihak Tekbek memberikan penjelasan dengan ilustrasi yang dapat menumbuhkan dan memberikan dampak positif bagi peserta untuk berusaha hidroponik. Pada sesi akhir dari kujungan ini pihak Tekbek menyajikan minuman hasil olahan sendiri dari tanaman hidroponik pakchoy.

Pada akhir kegiatan dilakukan penandatangan berita acara penyerahan dua unit perangkat instalasi hidroponik hasil dari kegiatan PKMI ini kepada peserta pelatihan, yaitu Kelompok Mepokoaso. Selain itu, diadakan pula penandatanganan nota kesepahaman antara Kelompok Mepokoaso dengan usaha hidroponik Tekbek. Isi nota kesepahaman tersebut adalah usaha hidroponik Tekbek bersedia memberikan bimbingan teknis dalam usaha budi daya hidroponik dan menjadi bapak asuh atas pengembangan usaha hidroponik Kelompok Mepokoaso.

Dengan kunjungan lapangan ke wirausaha hidroponik Tekbek dan penyerahan instalasi

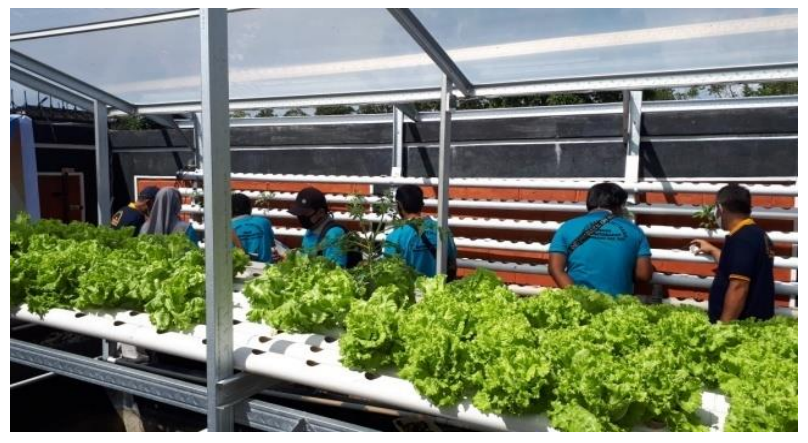

a

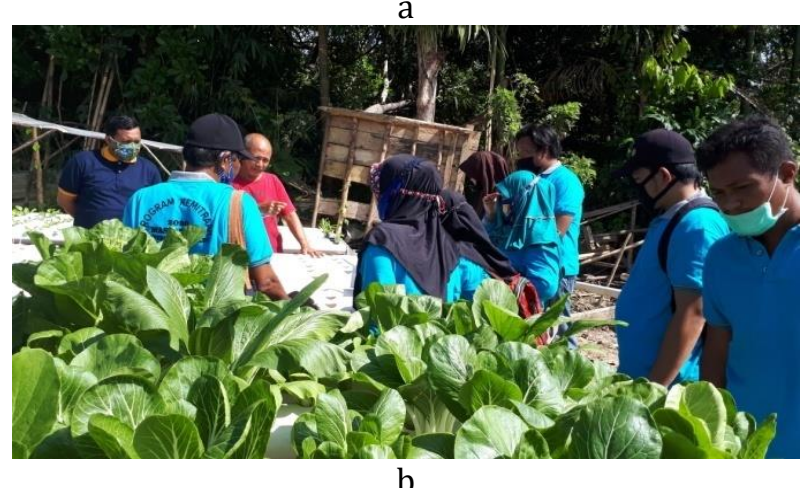

Gambar 8 a dan b Kunjungan ke kelompok hidroponik Tekbek. hidroponik beserta bahan pendukung lainnya ke peserta kegiatan maka diharapkan dari kegiatan ini memberikan dampak positif kepada peserta untuk memulai menanam dan mengembangkannya di masa mendatang sebagai wirausaha hidroponik. Diharapkan ada keberlanjutan kegiatan di masa mendatang karena peserta mendapat stimulus alat dan bahan dari hasil pelatihan. Selain itu, dengan kesediaan Kelompok Tekbek menjadi bapak asuh bagi peserta kegiatan akan membuat skema keberlanjutan kegiatan ini makin terbuka lebar.

Salah satu hasil kegiatan ini adalah telah terbentuknya grup WA yang diberi nama Pemasaran Hidroponik-PKMI. Keberadaan grup ini sebagai media komunukasi peserta kegiatan dengan tim PKMI UHO untuk memastikan keberlanjutan kegiatan ini. Selain itu, grup WA ini merupakan media pemasaran secara daring produk hidroponik yang dihasilkan oleh Kelompok Tekbek dan terkhusus untuk Kelompok Mepokoaso jika nantinya telah berproduksi. Grup WA ini difasilitasi oleh Tim PKMI sebagai admin dengan anggota grup adalah peserta pelatihan, kelompok Tekbek, dan memasukkan peserta lain dalam grup yang diperkirakan dapat menjadi pasar potensial pemasaran hidroponik. Hasil penelitian Tonnessen et al. (2021) menunjukkan bahwa peningkatan penggunaan platform digital membantu meningkatkan kinerja kreatif dalam pengaturan kerja dari rumah akibat pandemi. Pada aspek lain, Jacobson et al. (2020) menyatakan bahwa kenyamanan pemasaran mengacu pada kenyamanan individu dengan penggunaan informasi yang diposting secara publik di media sosial untuk iklan bertarget, hubungan pelanggan, dan penggalian opini.

Grup WA pemasaran hidroponik yang difasiltasi oleh tim PKMI ini diyakini akan mampu membuat kepercayaan publik tinggi untuk berada di grup tersebut dan dapat menerima tawaran produk hidroponik. Chen et al. (2020) menyatakan bahwa niat beli konsumen lebih dipengaruhi oleh kualitas sensorik dan manfaat yang dirasakan daripada harga. Penggunaan media sosial pada saat ini banyak memberikan manfaat dalam memperkenalkan atau memasarkan suatu produk. Hasil penelitian Chawla \& Chodak (2021) menunjukkan bahwa tautan web yang ditempatkan di komentar kiriman FB dengan tambahan keterangan akan lebih menguntungkan. Ilustrasi grup WA yang dimaksud ditunjukkan pada Gambar 9. 


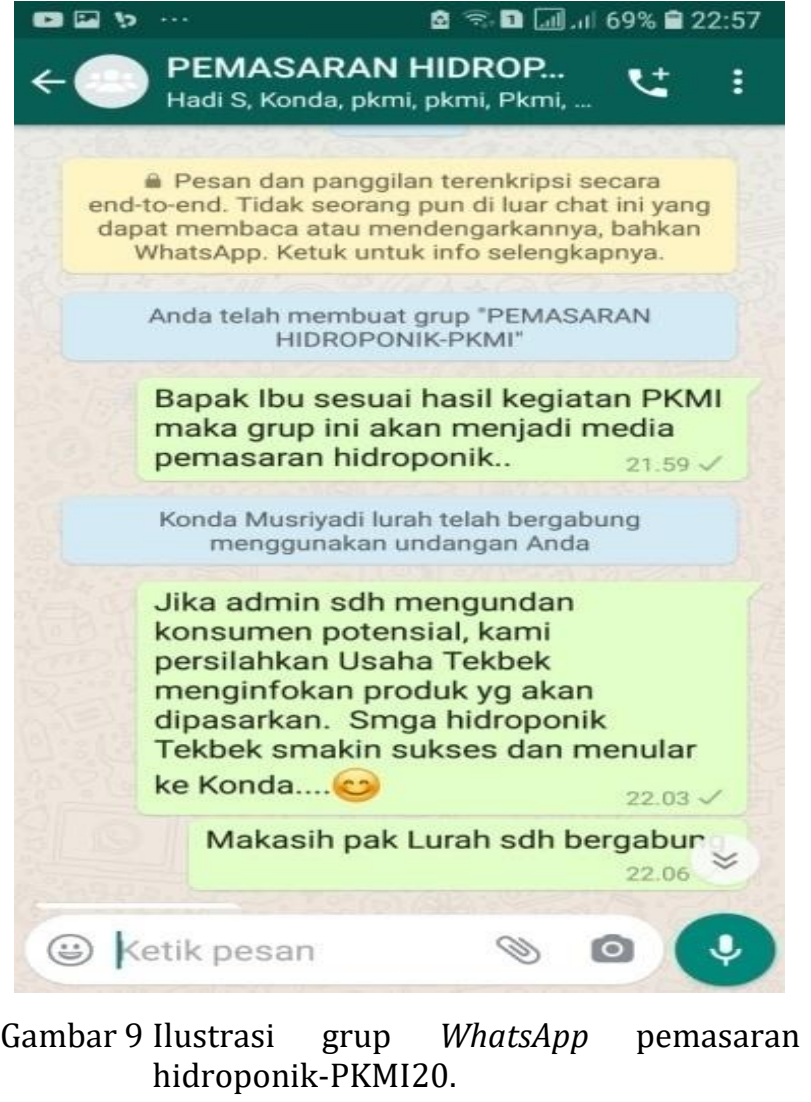

\section{SIMPULAN}

Kegiatan pelatihan introduksi teknologi budi daya hidroponik bagi kelompok calon wirausaha di masa pandemi Covid-19 dapat disimpulkan bahwa peserta dapat mengikuti dengan baik materi pelatihan dan bimbingan teknis perakitan instalasi serta praktik budi daya hidroponik. Manfaat dan tingkat kepuasan peserta dalam mengikuti kegiatan PKMI ini mencapai skor 8,75. Kegiatan ini meningkatkan minat peserta pelatihan untuk berwirausaha hidroponik. Sebelum mengikuti pelatihan terdapat 17\% peserta yang menyatakan ingin berwirausaha hidroponik. Pada akhir kegiatan pelatihan peserta yang menyatakan tertarik untuk berwirausaha hidroponik meningkat menjadi $67 \%$. Pada sisi budi daya menunjukkan bahwa kondisi tanaman yang dipanen belum memberikan hasil sebagaimana yang diharapkan, dengan hasil panen masih berada kisaran $50 \%$ dari potensi produksi yang dapat dicapai. Untuk memastikan keberlanjutan kegiatan dan memiliki dampak yang lebih meluas maka sebaiknya Pihak Kelurahan Konda dapat memfasilitasi agar peserta kegiatan ini dapat menjadi tutor bagi masyarakat lainnya yang ingin berwirausaha hidroponik.

\section{UCAPAN TERIMA KASIH}

Tim pelaksana pengabdian masyarakat mengucapkan terima kasih kepada Rektor Universitas Halu Oleo melalui Ketua Lembaga Penelitian dan Pengabdian Kepada Masyarakat yang telah memberikan dana kegiatan pengabdian masyarakat melalui skim Program

Kemitraan Masyarakat Internal (PKMI) Universitas Halu Oleo tahun anggaran 2020. Terima kasih kepada Camat Konda dan Lurah Konda yang telah memfasilitasi secara teknis atas jalannya kegiatan ini. Ucapan terima kasih ditujukan juga kepada Kelompok Usaha Hidroponik Tekbek yang telah memberikan peran berarti dalam kegiatan ini, dan kepada Kelompok Mepokoaso atas partisipasinya sebagai peserta kegiatan.

\section{DAFTAR PUSTAKA}

Berita Jakarta. 2020. Komunitas dasa wisma urban farming Pasar Baru panen 3,2 kilogram sayuran. [Internet]. [diunduh 2020 Juli 26]. Tersedia pada: http://www.beritajakarta.id/read/74828/ko munitas-dasa-wisma-urban-farming-pasarbaru-panen-32-kilogramsayuran\#.Xx4kap4zZnI.

Bibitonline. 2020. 8 Kelebihan budi daya tanaman secara hidroponik. [Internet]. [diunduh 2020 Juli 26]. Tersedia pada: https://bibitonline.com/artikel/8-kelebihanbudi daya-tanaman-secara-hidroponik.

Budastra IK. 2020. Dampak sosial ekonomi covid19 dan program potensial untuk penanganannya: studi kasus di Kabupaten Lombok Barat. Agrimansion. 21(1): 48-57. https://doi.org/10.29303/agrimansion.v21i1 .321

Chawla Y, Chodak G. 2021. Social media marketing for businesses: Organic promotions of web-links on facebook. Journal of Business Research. 135: 49-65. https://doi.org/ 10.1016/j.jbusres.2021.06.020

Chen H, Tong X, Tan L, Kong L. 2020. Consumers'acceptability and perceptions toward the consumption ofhydroponically and soil grown broccoli microgreens. Journal of Agriculture and Food. 2:1-6. https://doi.org/10.1016/j.jafr.2020.100051 
Distan Sukabumi. 2020 Kelebihan dan kekurangan bercocok tanam hidroponik. [Internet]. [diunduh 2020 Juli 27]. Tersedia pada:

https://distan.sukabumikota.go.id/kelebihan -dan-kekurangan-bercocok-tanam-

hidroponik/\#: :text=Kelebihan\%20sistem\% 20hidroponik\% 20antara\%20lain\% 3A\&text=Tanaman $\% 20$ berproduksi $\% 20$ tanp a\%20menggunakan\%20tanah, hama $\% 20$ dan $\% 20$ penyakit $\% 20$ lebih $\% 20$ mu dah.

Eikbuikwem PN, Mierzwa JC, Saroja DP. 2020. Assessment of suspended growth biological process for treatment and reuse of mixed wastewater for irrigation of edible crops under hydroponic conditions. Agricultural Water Management. 231: 1-12. https:// doi.org/10.1016/j.agwat.2020.106034

Jacobson J, Gruzd A, Hernandez-Garcia AA. 2020. Social media marketing: Who is watching the watchers?. Journal of Retailing and Consumer Services. 53: 1-12. https://doi.org/10.1016/ j.jretconser.2019.03.001

Kholis MN, Fraternesi, Wahidin LO. 2020. Prediksi dampak covid-19 terhadap pendapatan nelayan jaring insang di Kota Bengkulu. Albacore. 4(1): 1-11. https:// doi.org/10.29244/core.4.1.001-011

Kilmanun JC, Ndaru RK. 2020. Analisis pendapatan sayuran hidroponik di Malang Jawa Timur. Jurnal Pertanian Agros. 22(2): 180-185.
Mahi M, Mobin MA, Habib M, Akter S. 2021. A bibliometric analysis of pandemic and epidemic studies in economics: future agenda for Covid-19 research. Social Sciences \& Humanities Open. 4: 1-12. https://doi.org/ 10.1016/j.ssaho.2021.100165

Roidah IS. 2014. Pemanfaatan lahan pekarangan menggunakan sistem hidroponik. Jurnal Universitas Tulung Agung BONOROWO. 1(2): 43-49.

Sina PG. 2020. Ekonomi rumah tangga di era pandemi. Journal of Management. 12(2): 239254. https://doi.org/10.35508/jom.v12i2. 2697

Swardana A. 2020. Optimalisasi lahan pekarangan sebagai salah satu upaya pencegahan krisis pangan di masa pandemi covid-19. JAGROS. 4(2): 246-258. https://doi.org/10.52434/jagros.v4i2.922

Tallei TE, Rumengan IFM, Adam AA. (2017). Hidroponik Untuk Pemula. Manado (ID): UNSRAT Press.

Tonnessen 0, Dhir A, Flaten BT. 2021. Digital knowledge sharing and creative performance: Work from home during the Covid-19 pandemic. Technological Forecasting \& Social Change. 170: 1-13. https://doi.org/ 10.1016/j.techfore.2021.120866

Wahyuningsih A, Fajriani S, Aini N. 2016. Komposisi nutrisi dan media tanam terhadap pertumbuhan dan hasil tanaman pakcoy (Brassica rapa L.) sistem hidroponik. Jurnal Produksi Tanaman. 4(8): 595-601. 